\title{
Students' Financial Literacy and Parental Income
}

\author{
${\text { Dorjana } \mathrm{Nano}^{1}, \text { Emil Istrofor }}^{2}$ \\ ${ }^{1}$ University "Eqrem Cabej”, Gjirokaster, Albania \\ ${ }^{2}$ JobProAdvice, Ontario, Canada
}

\begin{abstract}
Financial literacy has become on focus of many research studies. Evidences have shown that financial literacy is beneficial for individuals, families and the community as it increases efficiency and financial wellness, improve the quality of living and makes the society more financially active. In addition, it is widely known that university student constitutes one of the most key segment of population. During this period, most students start to become financially independent and take financial responsibility. Studies undertaken in developed and developing countries have demonstrated that university students do not manage wisely their personal finance. One of the main factors found to influence their financial literacy is parental income. The purpose of this study is to explore the importance of students' financial literacy and whether there is any linkage between parental income and students' financial literacy. The main objectives of this research are: i) firstly, to review the existing literature regarding different definitions of financial literacy and its benefits. ii) secondly, to evaluate how financially literate are Albanian university students; ii) thirdly, to examine whether financial literacy differs based on the level of students' parental income; and iii) finally, to draw some conclusions and recommendations to improve student's financial literacy. An instrument comprised of personal finance and personal characteristics is administered to 637 students in Albania. The One Way Welch ANOVA and multiple comparison technique are utilized to analyze the data. The results indicate that student's financial literacy is influenced by their family income.
\end{abstract}

\section{Introduction}

Nowadays financial literacy has become a life skill for individuals. People have to meet their everyday needs and wants and planning for their future. It is necessary for them to be financially literate in order to make smart financial decisions. "Financial literacy is mostly considered as knowledge and understanding of financial concepts and risks, and the skills, motivation and confidence to apply such knowledge and understanding in order to make effective decisions across a range of financial contexts, to improve the financial wellbeing of individuals and society, and to enable participation in economic life" [1]. Financial literacy can be conceptualized on three dimensions: financial knowledge, financial behavior and financial attitude. University students constitute a very important segment of the population, since they are at a crucial time in life. Studies have shown that financial decisions made early in life establish habits that affect students' financial ability in their future. University students constitute an essential segment of the tomorrow financial market. Unfortunately, studies undertaken on developed and developing countries have found that today university students are not financially literate and display implementing behaviors [2]. They have more financial opportunities to spend compared to students in past generations, but in opposition they are found to be less financially literate.

One of the main factors found to impact students' financial literacy is parental influence. Studies have discovered that parents who discuss financial matters with their children impact positively their economic behavior and establish good habits for their future adulthood [3]. In addition, children who have benefited greater parental money management learning are found to experience less mortgage insolvency in their adulthood [4]. One way that children learn money management practices is their parents' financial behavior. It is found that higher parental income is associated with inadequate financial attitude. This in turn stimulates unreasonably financial behavior. According to [5] students who report high parental income are more prone to spending money, less interested in financial matters and see less need for precautionary saving. Family income serves as an indicator of a student's lifestyle, social class, and the resources and opportunity that are available to them.

Despite the large body of literature studying the relationship between family income and children financial literacy, there is still a lack of identifying this correlation in Albania. This research aims to identify the existing literature on financial literacy and also to investigate the impact of parental income on students' financial literacy in the case of Albania. The main objectives of this study are: 
$\checkmark$ Firstly, to review the existing research on financial literacy;

$\checkmark$ Secondly, to evaluate a financial literacy score of university students based on three dimensions: financial attitude, financial behavior and financial knowledge;

$\checkmark$ Thirdly, to reveal if there is any divergence on students' financial literacy based on their parental income;

$\checkmark \quad$ Finally, to provide some conclusions and recommendations in order to help parents and students to improve their financial practices.

The main hypothesis of this study is: Students' parental income influences their financial literacy.

\section{Conceptualization of Financial Literacy}

Despite there is no official definition of "financial literacy", many studies have provided different conceptualizations. In the first sense, "financial literacy" refers to the recognition and understanding of financial concepts, resulting in the ability to make informed financial decisions, with certainty and effectiveness. In general, financial literacy can be broadly defined or narrowly defined. A broad definition of financial literacy is related to "understanding of the economy" and how the circumstances and economic conditions affect consumer decisions [6]. The narrow definition of financial literacy focuses on the main means of money management, such as budgeting, savings, investment and insurance.

Literature defines financial literacy as (a) a particular form of financial knowledge, (b) ability to apply knowledge, (c) good financial behavior and (d) good financial attitude. One of the basic components of financial literacy under these definitions is knowledge or understanding [7]. In other definitions such as [8] emphasize decision making, which implies the attitude and financial behavior. Meanwhile, [9] considers knowledge, attitude and financial behavior as key components of financial ability.

Considering and categorizing the core of the above definitions, we can conclude that financial literacy includes several elements:

$\checkmark \quad$ Basic numerical skills, such as the ability to calculate the rate of return from an investment or debt interest rate;

$\checkmark$ The ability to understand basic financial concepts, risk-return relationship, different types of investments and other financial products, the benefits of diversification and the time value of money; $\checkmark \quad$ Positive attitude to personal finance;

$\checkmark$ Ability to apply sound financial behavior. This study, considers the official definition of the [10], according to which financial literacy includes three components: financial knowledge, financial attitude and financial behavior. Thus, a financially literate person should have basic knowledge of financial concepts, maintain a positive attitude towards money and have healthy behaviors towards personal finances. The following figure represents the conceptual model of financial literacy:

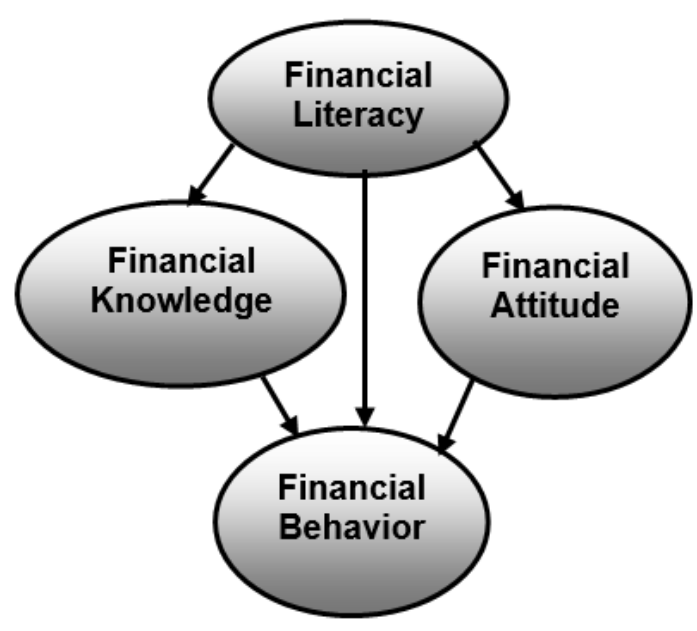

Figure 1. Conceptualization of Financial Literacy

\section{The Benefits of Financial Literacy}

Research has shown that financial literacy involves micro and macroeconomic benefits. Individuals' financial literacy makes them to have certain attitudes towards personal finance and develop particular financial behaviors. These microeconomic benefits are extended to other benefits for the financial system and the overall economy of a country.

\subsection{Benefits for Students}

The period of undergraduate studies is a key time in an individual's life. The financial habits that students have when they are at university tend to carry on when they grow up. The better their financial literacy when they finish school, the less problems and financial difficulties they may have later in life [11]. Financial literacy provides students with the knowledge and skills needed to optimally manage their personal finances. This is translated into many other short-term and long-term benefits.

3.1.1 Better Financial Behavior. Good financial behavior is achieved through the development of knowledge and skills that provide the basis for 
informed decision-making [12]. Financial literacy increases student opportunities to save and invest, to afford debts, to spend less than income, and to have a budget. Financial literacy also reduces bankruptcy opportunities as well as avoids poor financial decision making [13]. Students who lack financial knowledge are constantly faced with financial difficulties which are increasing considerably later in life.

3.1.2 Financial Efficiency. Financial efficiency involves selecting products based on the best value, and paying the lowest possible price. Financial education enhances financial knowledge and influences financial attitude by improving financial capability and efficiency [14]. Financial literacy is more than financial knowledge about money. It involves being smart consumers in buying food (to be healthy) and other purchases such as cars, houses and consequently affecting individuals' safety and the environment. [15] have found that students with less financial knowledge have more negative opinions about finances and make more wrong decisions. They emphasize that having a high level of financial knowledge increases student's ability to make informed and low-cost decisions. [16] conducted a study at university students in Iowa to assess the effectiveness of a personal finance workshop. Author measured financial knowledge, financial attitude and financial behavior before and after the workshop, and found that participants improved all the three components of financial literacy. Increased financial knowledge was found to have positive impact on students' attitudes towards the business and their skills becoming smart consumers in the market. [17] found that students want to obtain financial information and have preferences on how financial education is explained, who teaches, as well as on its content.

3.1.3 Financial Welfare. Financial welfare includes mainly property, income, savings, active debt management and investment. Many authors link students' financial behavior with their chances of having success in the future. [18] mentions that a high level of financial knowledge is positively linked with a high level and a regular source of income, as well as a high saving rate. Although perceived economic well-being varies by gender [19] identified that financial education "level the playing field" with respect to gender differences and is effective in changing knowledge, attitudes, and behaviors. Increasing financial knowledge through education has been found to have a positive relationship with risk tolerance, financial attitudes, savings and investment.

3.2 Benefits to the Financial System. Financial literacy has a significant impact on the efficiency of the financial system. It brings benefits to the financial system, particularly in increasing consumer involvement in financial markets and raising public awareness on financial issues. Hence, consumers make wise decisions in choosing the financial products and have a better understanding of the government financial policies.

3.2.1 Financial Inclusion. The more financially literate consumers are the greater will be the opportunity to get involved in financial products and services. For example, recognition of deposit terms may enable a person to gain more interest, while the lack of knowledge of the existence of such a product may result in the acquisition of a lower interest and an opportunity to lose. Financial ability makes individuals to better understand products and to become more financially active. Individuals who have received financial knowledge are more likely to be involved in the financial industry and do not pay high costs or carry high risk. Financial education encourages individuals, even those with low incomes, to plan and save some of their income. It also enhances financial involvement and gives people the knowledge they need to avoid high costs, risky debts and inadequate financial products.

3.5.2 The More Efficient Financial System. A financial literate consumer is expected to manage personal finances as well as to make smart choices of investment and financial products. Consequently, this will have the effect of reducing the risk of borrowing from banks and other lending institutions, as well as strengthening the measures taken by financial institutions to respond to consumer demand by promoting a more dynamic and efficient financial system. In addition, a financially literate company is prudent to the risk of financial institution products and is able to understand the risk-return ratio. Studying consumer financial risk promotes a stronger market discipline for financial products, and as a result stimulates better risk management by financial institutions and a higher standard of financial services. Moreover, well-informed investment decisions, resulting from a high level of financial literacy, result in better productive equity redistribution over time, reflecting on more cautious methods of balancing risk with return. Consequently, this contributes to a higher growth rate, to a lower cycle of economic instability, as well as to the longterm benefits of financial stability [19].

3.5.3 Better understanding of Government Financial Policies. Financially educated individuals are able to assess government financial policies and the actions of financial institutions. This makes customers well-informed and able to understand policies in the financial sector. For example, financial literacy promotes the understanding and 
acceptance of important reforms in various sectors such as health, education or pension reform as well as enhances the public's ability to criticize nontransparent government policies.

\subsection{Benefits to the Economy}

In addition to the benefits for the individual and the financial system, financial literacy has important implications for the overall economy. As mentioned above, the potential growth of the economy in the long term is influenced by the productive distribution of resources. Considering all the other factors unchanged, the higher rate of return adjusted by the higher risk is expected to be the long-term rate of economic growth. Financial literacy can affect the distribution of resources in the economy. If investors are financially literate, they are more likely to be better able to apply investment strategy methods, being more sensitive and prudent to the investment risk as well as to the risk-return ratio. Financially literate investors are most likely to be positioned to maximize the adjusted rate of return from their investment risk. Consequently, it is likely that resources will be allocated more efficiently, resulting in a higher rate of economic growth and in a low economic volatility.

\section{Research Methodology}

Data for this study are provided by a randomly selected sample from five state universities and two private universities in Albania. The population of state and private universities is 160,839 students in total, $78.5 \%$ of which study in state universities (MAS 2014). The public universities involved in this study are: University of Tirana; University "Aleksander Moisiu", Durrës; University "Aleksandër Xhuvani", Elbasan; University "Eqrem Çabej", Gjirokastra; and Agricultural University of Tirana. Meanwhile, private universities included in this study are: University "Marin Barleti", Tirane; and the "Kristal" University, Përmet Branch. In this study participated 637 Bachelor and Master students, mostly 18-30 years old, attending the full-time program. Participants of this survey were involved in different areas of study: law, journalism, economics, agribusiness, history - geography and medicine. In order to provide the necessary data, a questionnaire is delivered during the class time. This technique creates opportunities to clarify participants about any uncertainty in filling the questionnaire. In addition, this method is efficient in terms of cost and time.

\subsection{Measuring Instrument}

The instrument used in this study is designed based on the existing literature on student financial literacy. Financial literacy is conceptualized in three dimensions: financial attitude, financial behavior and financial knowledge. Thus, the questionnaire is divided into two parts. The first part consists of 42 questions and expressions that measure the students' financial literacy based on its three dimensions. The second part considers 14 personal questions, which provide information on socio-demographic factors such as age, sex, parental income, work experience, academic status, field of study, etc.

4.1.1 Evaluation of the questionnaire. The first part of the questionnaire measuring financial literacy is divided into three sections that test the three components of financial literacy: financial attitude, financial behavior, and financial knowledge.

4.1.1.1 "Financial Attitude" Section. Financial attitude is a very important component of financial literacy. If an individual has a negative attitude towards saving, there is more likely for not saving money. This section is focused on measuring the attitude towards money and managing personal finances. Specifically, this section consisted on a subjective question that measures how safe participants feel about money management, and ten statements that measure students' perceptions on money and personal finances. For the first question (How safe are you in money management), there are five options for answers (1 - Not at all safe, 2 - Not very safe, 3 - Neutral, 4 - Somewhat safe, 5. Very safe). The second question consisted on nine statements (a-g) and there are five options for the answer: 1. I disagree 2. I disagree, 3. Neutral, 4. I agree, 5 . I fully agree.

In order to obtain an assessment for the financial attitude and to include this score in the overall assessment of the financial literacy, it is estimated one point for every answer at 4 or 5 scale, and 0 in any other cases.

4.1.1.2 "Financial Behavior" Section. Financial behavior is considered as one of the most important elements of financial literacy. Financial literacy results in good financial behavior such as spending planning, building a secure future, etc. In contrary, unhealthy financial behavior would result in misuse of credit cards, mismanagement of debt, meeting short-term needs without planning for future security, etc. Questions involved in this section test the way of managing personal finances and the evaluation is based on the 5 level Likert Scale- 1 . Not at all true to me, 2. Not true to me, 3. Neutral, 4. Somehow true to me, and 5. Very true to me. For example: Before I buy a product, I always think carefully if I can afford it or not.

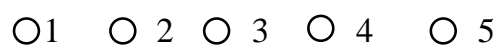


Students who select 4 "Somehow true to me", or 5 "Very true to me" are considered to display good financial behavior.

In order to obtain an assessment for the financial behavior and to include this score in the overall assessment of the financial literacy, it is estimated one point for every answer at 4 or 5 , and 0 in any other case.

4.1.1.3 "Financial Knowledge" Section. A financially literate person will have knowledge of basic financial concepts as well as knowledge about savings and investments, insurance, and borrowing. This section includes four parts: general knowledge, savings and investments, insurance and borrowing.

General knowledge. This part consists on nine questions that test student knowledge about the importance of personal finance, identifying the most liquid assets, the instrument providing more interest, the discount calculations, and other questions testing basic financial concepts. Questions involve multiple alternatives and participants have to choose the correct alternative. For example:

\section{Personal finance knowledge helps you more to:}

- Avoid financial hardship.

- Buy proper insurance in order to be protected from any catastrophic risk.

- Learn the right ways to invest for future needs.

- Ensure a safe financial life through healthy spending behaviors.

Saving and Investing. This part includes seven questions that test student knowledge about simple and compound interest, liquidity, inflation, portfolios diversification, interest rates and mathematical calculations for future savings. Questions involve multiple alternatives and participants have to choose the correct alternative. For example:

Suppose that the annual interest earned on your bank deposit is $8 \%$, while the annual inflation rate is 10\%. Do you think that you can buy more, less, or the same quantity of products compared to

- a year ago.

- More than a year ago.

- The same amount.

- Less than a year ago.

- Cannot be defined

Insurance. This part includes four questions that test student knowledge about the importance of insurance, accident insurance, as well as social and health insurance paid by the employer and the employee. Questions involve multiple alternatives and participants have to choose the correct alternative. For example:

How much of the gross salary should be paid from the employer on behalf of the employee for social and health insurance?

- $16.7 \%$

- $11.2 \%$

- $21.7 \%$

- None of the above alternatives.

Borrowing. This part includes three questions that test the ability of students to assess the right information on obtaining a bank loan, bad debts knowledge and legal responsibilities in the case of a loan co-financed. Questions involve multiple alternatives and participants have to choose the correct answer.

For example:

If you sign up with a friend a bank loan on his behalf, then you:

- You can get a share of the principal.

- Become a guarantor for your friend's trust, but you have no legal obligation on the loan.

- You are responsible for repaying the loan if your friend fails to repay.

- You have the benefit of getting a personal loan.

In order to obtain an assessment for the financial knowledge and to include this score in the overall assessment of the financial literacy, it is estimated one point for every answer at 4 or 5 , and 0 in any other case.

\subsection{Data Management}

Data management of this survey are carried out in two phases. The first phase consists in clearing and omitting the data in the SPSS 20 program, and the second phase consists in analyzing data. Questionnaires completed for at least $90 \%$ are taken into consideration. The response rate of the questionnaires is $95 \%$. Data entry into the program is done based on data encryption, which is performed based on the relevant sections and questions.

In addition to counting the high scores, there are summed the three scores into an overall indicator of financial literacy which takes values from 0 to 42 .

4.2.1. Validation. The validity of an instrument shows how well the instrument measures what is supposed to measure. Existing literature demonstrates two types of validity - the validity of the content and the validity of the construct. The validity of the content is determined by the logic of questions about addressing the topic. While the validity of the construct is determined by the size with which a measure represents all facets of a given construct. To improve the validity of the 
questionnaire content two experts have worked independently to evaluate each section of the questionnaire. Experts were asked to assess whether the instrument used was appropriate to measure the financial ability of students in Albania. After considering the suggestions of the experts, a pilot study with 30 students is conducted to test the clarity of the questionnaire. Participants are asked about the clarity of the questions in the questionnaire, the difficulties of completing, the time needed to fill in, any mistakes in the questionnaire and whether any questions were inappropriate. Comments and suggestions of the pilot study are evaluated and included in the final questionnaire.

Meanwhile, factor analysis is considered to test the validity of the construct. The smaller the sample, the greater the possibility that the correlation coefficient of the sample changes from the coefficient of factor correlation to other cases. A rule of thumb in this case would be 10-15 participants for question. In the case of this study the sample is large $(n=607)$ and the factorial analysis is required. Another test that confirms the necessity of factor analysis is the KMO test (Kaiser-Meyer-Okin), which demonstrates the variance of variables explained by the inclusive factors in this variable. The high value (close to 1) of the KMO test demonstrates the usefulness of the factor analysis, while values smaller than 0.5 indicate that it is not necessary to undertake factorial analysis. Table 1 below demonstrates that the KMO values for the three sections are almost 0.8 , thus confirming the importance of factorial analysis. The last step to take before performing the factor analysis is the Barlett test, which tests the hypothesis that the correlation matrix is an identical matrix, which means that the variables are not related and are not suitable for structure identification. Values less than 0.05 of the significance of this test indicate the necessity of factorial analysis. Table above demonstrates a zero value of the Barlett test significance reconfirming the usefulness of factor analysis.

Table 1. KMO test and Barlett test

\begin{tabular}{|l|l|l|l|}
\hline & $\begin{array}{l}\text { Session } \\
\text { Financial } \\
\text { Attitude }\end{array}$ & $\begin{array}{l}\text { Session } \\
\text { Financial } \\
\text { Behavior }\end{array}$ & $\begin{array}{l}\text { Session } \\
\text { Financial } \\
\text { Knowled } \\
\text { ge }\end{array}$ \\
\hline KMO & 0.794 & 0.802 & 0.748 \\
\hline $\begin{array}{l}\text { Chi } \\
\text { Square }\end{array}$ & 3099.347 & 2768.946 & 6053.859 \\
\hline df & 55 & 28 & 253 \\
\hline $\begin{array}{l}\text { Batlett } \\
\text { test sig. }\end{array}$ & .000 & .000 & .000 \\
\hline
\end{tabular}

One of the most appropriate techniques to test the validity of the construct is the "maximum likelihood" method (EFA), which tests the suitability of the factors. The zero hypothesis in the factorial exploration analysis based on this method is that the number of factors fits with the data. If the zero hypothesis is rejected, the model with the highest number of factors is accepted. Factors loading less than three are excluded from the questionnaire. The EFA is performed for each section and repeated every time that any factor is excluded. From the financial attitude analysis it is found that the phrase "How Safe Do You Feel on Money Management?" and "I Think Credit Cards are Safe and Risk-Free" have a load factor of less than three and are removed from the analysis. In the "Financial Behavior" section all factors loaded greater than 0.3. Based on the factorial exploration of the Financial Knowledge Section comprised of 23 questions it is found that 7 of them have a factor loading less than three. The terms that removed are: "Personal finance knowledge helps you more," "Net value is presented as", "The difference of money held by your gross salary", "Increase in inflation increases the cost of living", Liquid asset is... ", " It is likely that you will lose all your money if you have invested in many places, " and "If you sign a bank loan with a friend on his behalf...". The analysis has identified two general dimensions of financial knowledge: general financial knowledge and specific financial knowledge. Tables 2 and 3 below demonstrate the final results of the factor analysis after factors loading less than three are excluded.

4.2.2 Sustainability. Sustainability measures how stable it is an instrument in its measurements in different times and situations. In other words, if a survey is to be carried out several times, then the results should be almost the same, with little change. Systematic and random errors make the results unreliable and changeable. A high reliability coefficient indicates sustainability in results but does not necessarily indicate that the test has made accurate measurements. In this way, we can say that an instrument can be stable without being valid but cannot be valid without being stable. The sustainability of the questionnaire considered in this study is based on the Cronbach Alpha coefficient. This indicator measures the reliability and sustainability of each section and the entire questionnaire. A coefficient of 0.7 or above is considered "acceptable". Information below represents the Cronbach Alpha coefficient for the three sections and for the overall questionnaire.

Financial Sustainability 0.7149

Financial Behavior 0.7178

Financial Knowledge 0.70016

The Overall Questionnaire 0.77033 
Table 2. Factorial Exploration Analysis for the Financial Stability Section and Financial Behavior

\begin{tabular}{|l|l|c|}
\hline & Financial Attitude Session & $\begin{array}{c}\text { Factor } \\
\text { loading }\end{array}$ \\
\hline 1 & Keeping financial records & .379 \\
\hline 2 & To spend less than your income & .459 \\
\hline 3 & I think I control my financial situation & .707 \\
\hline 4 & $\begin{array}{l}\text { I think I am capable of using my future income to achieve my financial } \\
\text { goals. }\end{array}$ & .574 \\
\hline 5 & I'm sure about spending money & .423 \\
\hline 6 & $\begin{array}{l}\text { I think it is very important to set aside each month a sum of money in order } \\
\text { to invest or deposit. }\end{array}$ & .358 \\
\hline 7 & I think life insurance is very important to protect the most beloved people & .437 \\
\hline 8 & $\begin{array}{l}\text { I think before signing a debt contract or flat rent contract, it is very important } \\
\text { to understand the contract. }\end{array}$ & .507 \\
\hline 9 & I like to discuss with my friends / colleagues about money management. & 0.374 \\
\hline & Financial Behavior Session & .562 \\
\hline 1 & How do you classify yourself? & .616 \\
\hline 2 & How do you usually manage your daily earnings? & .673 \\
\hline 3 & I plan and control the costs. & .472 \\
\hline 4 & I compare prices before I go shopping. & .336 \\
\hline 5 & I read to increase my financial knowledge. & .446 \\
\hline 6 & I pay bills on time. & .384 \\
\hline 7 & I did not borrow to close the month. & .506 \\
\hline 8 & Always before you buy a product, I think carefully if I can afford it or not. \\
\hline
\end{tabular}

Table 3. Factorial Exploration Analysis for the Financial Knowledge Section

\begin{tabular}{|c|c|c|c|}
\hline \multirow[b]{2}{*}{ №. } & \multicolumn{3}{|l|}{ Financial Knowledge Session } \\
\hline & Factor & $\begin{array}{l}\text { General Knowledge } \\
\text { Factor Loading }\end{array}$ & $\begin{array}{l}\text { Specific Knowledge } \\
\text { Factor Loading }\end{array}$ \\
\hline 1 & Personal financial planning includes: & .310 & .039 \\
\hline 2 & The most liquid asset is: & .303 & .014 \\
\hline 3 & $\begin{array}{l}\text { Which of the investments provides more } \\
\text { interest? }\end{array}$ & .384 & .006 \\
\hline 4 & $\begin{array}{l}\text { Which of the following expressions is not true } \\
\text { for any ATM? }\end{array}$ & .395 & -.200 \\
\hline 5 & $\begin{array}{l}\text { How much will be the price of a } 100,000 \text { Lek } \\
\text { TV, if it will be sold at } 20 \% \text { discounts? }\end{array}$ & -.369 & .234 \\
\hline 6 & $\begin{array}{l}\text { If you invest } 100,000 \text { Lek today with } 10 \% \\
\text { annual interest, how much will you have on } \\
\text { account in a year? }\end{array}$ & -.239 & .300 \\
\hline 7 & $\begin{array}{l}\text { Assume that the interest earned at the end of } \\
\text { each year is added to the principal. How much } \\
\text { money will you have on your account after } 5 \\
\text { years if you do not attract principal or interest } \\
\text { during this period? }\end{array}$ & -.025 & .366 \\
\hline 8 & Suppose the annual interest earned on your & -.067 & .330 \\
\hline
\end{tabular}


Table 4. ANOVA

\begin{tabular}{|l|r|r|r|r|}
\hline & Mean & $\begin{array}{l}\text { Standard } \\
\text { Deviation }\end{array}$ & \multicolumn{1}{l|}{ Skewness } & \multicolumn{1}{l|}{} \\
\hline $0-20,000$ Lekë & $57.25 \%$ & 12.672 & -0.58 & 0.219 \\
\hline $\begin{array}{l}\text { Greater than } 20,000- \\
40,000 \text { Lekë }\end{array}$ & $59.79 \%$ & 13.402 & -0.337 & 0.17 \\
\hline $\begin{array}{l}\text { Greater than } 40,000- \\
60,000 \text { Lekë }\end{array}$ & $63.24 \%$ & 14.704 & -0.528 & 0.312 \\
\hline $\begin{array}{l}\text { Greater than } 60,000- \\
80,000 \text { Lekë }\end{array}$ & $59.75 \%$ & 13.476 & -0.004 & -0.656 \\
\hline $\begin{array}{l}\text { Greater than } 80,000 \\
\text { Lekë }\end{array}$ & $58.75 \%$ & 14.387 & -0.516 & 0.295 \\
\hline Differences between groups & $\mathrm{F}=10.340$ & \multicolumn{2}{|c|}{ Sig. 0.000} \\
\hline
\end{tabular}

Table 5: Post Hoc Tukey Comparison

\begin{tabular}{|c|c|c|c|c|c|}
\hline & $\begin{array}{l}\text { (J) Family Income } \\
\text { (in thousand Leke) }\end{array}$ & $\begin{array}{l}\text { Mean } \\
\text { Differ. (I-J) }\end{array}$ & Sig. & $\begin{array}{r}95 \% \\
\text { Interval }\end{array}$ & nfidence \\
\hline \multirow{4}{*}{$\begin{array}{l}0-20,000 \\
\text { Leke }\end{array}$} & Greater than $20-40$ & -2.541 & .119 & -5.45 & .36 \\
\hline & Greater than $40-60$ & $-5.989^{*}$ & .000 & -8.93 & -3.05 \\
\hline & Greater than $60-80$ & -2.506 & .155 & -5.52 & .51 \\
\hline & Greater than 80 & -1.506 & .677 & -4.61 & 1. 60 \\
\hline \multirow{4}{*}{$\begin{array}{l}\text { Greater than } \\
20,000 \text { - } \\
40,000 \text { Leke }\end{array}$} & $0-20$ & 2. 541 & .119 & -.36 & 5.45 \\
\hline & Greater than $40-60$ & $-3.448^{*}$ & .000 & -5.74 & -1.16 \\
\hline & Greater than $60-80$ & .035 & 1. 00 & -2.35 & 2. 42 \\
\hline & Greater than 80 & 1.035 & .790 & -1.46 & 3.53 \\
\hline \multirow{4}{*}{$\begin{array}{l}\text { Greater than } \\
40,000-60 \text {, } \\
\text { 000 Leke }\end{array}$} & $0-20$ & $5.989^{*}$ & .000 & 3.05 & 8.93 \\
\hline & Greater than 20-40 & 3. $448^{\star}$ & .000 & 1. 16 & 5.74 \\
\hline & Greater than $60-80$ & $3.483^{\star}$ & .001 & 1. 06 & 5.91 \\
\hline & Greater than 80 & 4. $483^{\star}$ & 000 & 1. 94 & 7.02 \\
\hline \multirow{4}{*}{$\begin{array}{l}\text { Greater than } \\
60,000 \text { - } \\
80,000 \text { Leke }\end{array}$} & 0 -20 leke & 2. 506 & .155 & -.51 & 5.52 \\
\hline & Greater than $20-40$ & -.035 & 1. 000 & -2.42 & 2. 35 \\
\hline & Greater than $40-60$ & $-3.483^{\circ}$ & .001 & -5.91 & -1.06 \\
\hline & Greater than 80 & 1.000 & .837 & -1.62 & 3.62 \\
\hline \multirow{4}{*}{$\begin{array}{l}\text { Greater than } \\
80,000 \text { Leke }\end{array}$} & 0-20 leke & 1.506 & 677 & -1.60 & 4. 61 \\
\hline & Greater than 20-40 & -1.035 & .790 & -3.53 & 1. 46 \\
\hline & Greater than $40-60$ & $-4.483^{\circ}$ & .000 & -7.02 & -1.94 \\
\hline & Greater than $60-80$ & -1.000 & .837 & -3.62 & 1. 62 \\
\hline
\end{tabular}

The confidence coefficient for the "Financial Attitude" section (questions 1 and 2) is 0.714. The coefficient for the "Financial Behavior" section (questions 3, 4 and 5) is 0.717 and the coefficient for the "Financial Knowledge" section (questions 6-28) is 0.7 . Meanwhile, the confidence coefficient for the entire questionnaire is 0.770. Statistics show that each section and the whole questionnaire has a very high consistency, since all Cronbach Alpha coefficients meet the criterion. 


\section{Data Analysis and Results}

This survey is conducted on 637 university students in Albania. The response rate of the survey stands at 95\% (607/637). Based on statistics of the survey the minority of participants $(10.6 \%)$ have displayed minimal $(0-20000$ Lekë $)$ parental income. Approximately half of the respondents (48. $1 \%$ ) have declared middle or lower middle family income (greater than 20000 Lekë - 60000 Lekë), and $36.6 \%$ reported upper middle or high family income (greater than $60000-80000$ Lekë, or greater than 80000 Lekë).

\subsection{Financial Literacy}

In this section it is examined the MPCS of participants financial literacy and are made relevant comparisons based on family income. Table 4 below provides meaningful evidence about the MPCS, standard deviation, skewness and kurtosis.

The distribution of MPCS values is viewed as normal since the values of skewness and kurtosis are close enough to zero. Statistics demonstrates that Albanian university students are not financially literate. The MPCS are shown to be less than the threshold level of $65 \%$. Although the low level of financial literacy, great differences are found among different categories of participants. Results of analyze of variance reveal students with middle household income to score higher on financial literacy $(\mathrm{MPCS}=63.24 \%)$, followed by students with lower - middle and upper - middle household income (MPCS $=60 \%$ ). The least values of financial literacy scores are discovered among students with higher family income (MPCS $=58.75 \%$ ) and minimal family income (MPCS $=57.25 \%$ ). Findings of the F-test examine these differences to be statistically significant $(\mathrm{p}=0.00)$ at $5 \%$ level of significance using the predetermined Type I error rate of $\alpha=0.05$.

Results of analyze of variance are confirmed by the Tukey Hoc technique (table 5), which considers multiple comparisons among different categories. These results confirm that parental income influences students' financial literacy.

\section{Conclusions, Discussions and Recommendations}

This research surveys 637 students from five public and two private universities across Albania. It investigated the existing literature about the definitions and benefits of financial ability as well as about students' knowledge, attitudes and attitudes toward personal finance. Despite the lack of an official definition of financial literacy, literature research concluded that financial capability includes three main components: financial knowledge, financial attitudes, and financial behaviors. According to different studies, financial literacy brings microeconomic and macroeconomic benefits, as it increases financial efficiency and prosperity, improves the quality of life, and makes the company more financially active. Literature showed that students do not have the necessary financial knowledge and attitudes to have good financial behavior. This study demonstrated that individuals change slowly their financial behavior because the benefits of change are not immediate. In addition, it demonstrated that students' financial literacy differs due to financial education and personal factors.

Results of analyze of variance suggest that university students are not financially literate. The mean percentage of correct score differs among different groups of students and stands less than $65 \%$ for each category. Results of this study provide evidence that parental income influence financial literacy of their children. Lower level of financial literacy is discovered among students with minimal family income and those with higher household income. The most financially literate are shown to be students who have declared middle family income.

Results of this research can be mainly explained by the fact that students with higher households' income may not have the right financial attitude towards money management. Since they have all the opportunities to fulfill their wants and needs, they do not need to prioritize their budget, to track expenses and being careful about money management practices. Contrary, students with middle parental income may have learned that money matters. Parents' financial behavior is the first model for their children. They can teach children that "money is there to be spent", or "Money Matters". In concert with other previous research on this topic, this study suggests parents to be aware about their role on teaching children good financial habits. Training parents on how to teach children smart financial attitude and behavior will make them capable to model constructive financial habits in the home.

The relationship between minimal household income and students' financial literacy appears to be flaw in this study. Hence, future research it is recommended to be undertaken to investigate this association. Further quantitative research can also be conducted utilizing different techniques of study like logistic regression. Finally, qualitative study would be valuable to explicate in depth the causes and consequences of the role of parental income on their children financial literacy.

\section{References}

[1] OECD PISA 2012 Results, "Students and Money: Financial Literacy Skills for the 21st Century," PISA 
OECD publishing, Vol. 6, pp. 33, 2014. [Online] Available http:/dx. doi. org/10. 1787/9789264208094-en (9 September 2016).

[2] T. K. Hira and C. S. Brinkman, "Factors Influencing the Size of Student Debt, "Journal of Student Financial Aid" Vol. 22 pp.2, 1992, [Online] Available: http://publications, nasfaa. org/jsfa/vol22/iss $2 / 3 \quad$ (15 September 2016).

[3] W. Paul and K. E. Nyhus, "Parents' Influence on Children's Future Orientation and Saving", Journal of Economic Psychology, Vol. 27, p. 140 - 164, 2006.

[4] G. W. Michal, S. S. Jonathan, H. Y. Yeong, C. K. Clinton, and E. B. Freeze, "Loan Performance among Low Income Households: Does Prior parental teaching of Money Management Matter?", Social Work Research, Vol 4, pp. 257-270, 2012.

[5] C. A. Robb and M. B. Pinto, "College Students and Credit Card Use: Analyses of Financially at-Risk Students", College Students Journal, Vol. 44, pp. 823, 2010.

[6] Worthington, A., (2006): Predicting Financial Literacy in Australia, Financial Services Review, 15: 59.

[7] Garman, E. T., Forgue, R. E., (2006): Personal Finance (7th ed.). Boston: Houghton Mifflin Co, 2006.

[8] Mandell, L., (1997): Personal Financial Survey of High School Seniors. The Jump\$tart Coalition for Personal Financial Literacy, Washington, D.C, March/April 1997.

[9] Lusardi, A., Mitchell, O. S., (2005): Financial Literacy and Planning: Implications for Retirement Wellbeing. University of Michigan, Michigan Retirement Research Center, Research Paper No. WP 108.

[10] OECD (2013): OECD Guidelines on Measuring Subjective Well -Being, OECD Publishing; http://dx.doi.org/10.1787/9789264191655-en (February 2017).

[11] Grable, J. E., Joo, S., (1998): Does Financial Education affect Knowledge, Attitudes, and Behavior? An empirical analysis. Journal of Personal Finances and Worker Productivity, 2(2): 213- 220.

[12] Volpe, R.P., Chen, H., Pavlicko, J.J., (1996): Personal Investment Literacy among College Students: A Survey. Journal of Financial Practice and Education, 6(2): 86-94. [13] Bauer, J. W., Braun, B., Olson, P. D., (2000): Welfare to Well-being Framework for Research, Education, and Outreach. The Journal of Consumer Affairs, 34(1): 62-81.

[14] Grable, J. E., Joo, S., (1998): Does financial education affect knowledge, attitudes, and Behavior? An empirical analysis. Journal of Personal Finances and Worker Productivity, 2(2): 213- 220.

[15] Chen, H., Volpe, R. P., (1998): An Analysis of Personal Financial Literacy among College Students. Financial Services Review, 7(2): 107-128.
[16] Fletcher, C.N., Beebout, G., \& Mendenhall, S., (1997): Developing and evaluating personal finance education at the worksite: A case study. In E. T.Garman, J. E. Grable, S. Joo (Eds.), Journal of Personal Finances and Worker Productivity 1(1):54-59, Roanoke, VA.

[17] Lyons, A. C., Hunt, J. L., (2003): The Credit Practices and Financial Education Needs of Community College Students. Journal of Association for Financial Counseling and Planning, 14(1), 63-74.

[18] Danes, S. M., Hira, T. K. (1987): Money Management Knowledge of College Students. Journal of Student Financial Aid, 17(1): 4-16.

[19] Widdowson, D., Hailwood, K., (2007): Financial Literacy and Its Role in Promoting a Sound Financial System. Reserve Bank of New Zealand: Bulletin, 70 (2): 37-47.

[20] Beal J. D, Delpachitra B. Sarath., (2003): Financial Literacy among Australian University Students. Journal of Economic Papers, 22(1): 65-78. 